\title{
PENINGKATAN KUALITAS PEMBELAJARAN KULIAH LAPANGAN GEOLOGI PADA MAHASISWA GEOGRAFI FKIP UNDANA MELALUI LESSON STUDY
}

\author{
Muhammad Husain Hasan ${ }^{\mathrm{a}}$ \\ ${ }^{a}$ Jurusan Pendidikan Geografi FKIP Undana, Jln. AdisuciptoPenfui Kupang, Kode Pos 85001, NTT, Indonesia
}

\begin{tabular}{ll}
\hline INFO ARTIKEL & ABSTRACT \\
\hline Status artikel: & Geology is one of subject course in Geography Study which requires field studiy. \\
Diterima: 01-02-2021 & Field studies that have been carried out so far are considered less effective because it \\
Disetujui: $15-02-2021$ & has weaknesses from various aspects. The research method used was a descriptive \\
Tersedia online: $04-03-2021$ & survey. Data collection techniques by observation and interviews. The results showed \\
& that the geology topic field lecture activity at the first location was not optimal with a \\
Kata kunci: & mean score of 80 pre-field observations, 60 on field activities, and 65 on activity \\
Geologi, Lesson Study, Kuliah & reporting followed by learning reflections. Geological field course activities at the \\
Lapangan & second location showed improvements where the results of the reflections at the first \\
& location were used to improve the quality at the second location so that observations \\
Penulis korespondensi: & 75 in activity reporting. \\
Muhammad Husain Hasan &
\end{tabular}

Pendidikan Geografi FKIP Undana,

Kupang, Indonesia

Email:

muhammadhusain@staf.undana.ac.id DOI: 10.34312/jgej.v2i1.10691

\begin{abstract}
ABSTRAK
Mata kuliah geologi merupakan salah satu mata kuliah bidang keahlian pada Program Studi Pendidikan Geografi yang mengharuskan adanya pembelajaran lapangan. Pembelajaran lapangan yang selama ini dilakukan dianggap kurang efektif karena memiliki kelemahan dari berbagai aspek. Metode penelitian yang digunakan adalah deskriptif survey. Teknik pengumpulan data dengan observasi dan wawancara. Hasil Penelitian menunjukkan bahwa kegiatan kuliah lapangan topik geologi pada lokasi pertama belum maksimal dengan rerata skor observasi 80 pra lapangan, 60 pada kegiatan lapangan, dan 65 pada pelaporan kegiatan yang dilanjutkan dengan refleksi pembelajaran. Kegiatan kuliah lapangan geologi pada lokasi kedua menunjukkan perbaikan dimana hasil refleksi pada lokasi pertama digunakan untuk memperbaiki kualitas pada lokasi kedua sehingga diperoleh hasil observasi dengan rerata skor 80 pada pra lapangan, 77 pada kegiatan lapangan, dan 75 pada pelaporan kegiatan.
\end{abstract} Copyright $(0) 2021$ The Authors.

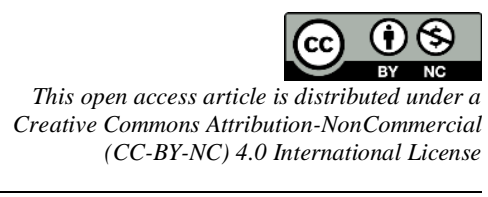

\section{Pendahuluan}

Geografi merupakan ilmu yang menjembatani antara ilmu alam dan ilmu sosial. Menurut (Prasad, 2013), fenomena geografi berupa kenampakan objek pada ruang permukaan bumi. Menurut (Yunus, 2010), karateristik geografi pada hakekatnya menguraikan fenomena, dan berdasarkan ekspresi keruangnnya. (Alfandi 2001). Dalam kajian fisiogeografi, mahasiswa geografi mempelajari tentang fenomena batuan, tanah, bentuklahan, iklim, air sedangkan dalam kajian sosiogeografi terdapat fenomena penduduk, interaksi sosial, ekonomi, budaya, dan politik. Salah-satu bidang kajian fisiogeografis adalah batuan yang dipelajari dalam mata kuliah geologi. Kompleksitas materi geologi menuntut adanya pembelajaran di lapangan. Geologi sebagai matakuliah yang mengkaji tentang planet bumi, bahan pembentuk bumi, sejarah bumi, dan proses-proses yang terjadi, tentang komposisi, struktur, sifat, sejarah, dan proses pembentukan bumi, (Zuhdi, 2019)

Mata kuliah geologi memerlukan kualitas pembelajaran yang mampu menyiapkan ruang untuk mahasiswa memahami konsep dan realitas fenomena diluar kelas. Mengidentifikasi dan menganalisis obyekobyek geologi sesuai teori yang telah diperoleh dilapangan. Pada kenyataannya pembelajaran matakuliah geologi yang berjalan, Dosen belum mampu mempersiapkan mahasiswa untuk memahami fenomena geologi 
secara komrehensip. Persiapan, pengelolaan hingga pada proses evaluasi mahasiswa yang dijalankan oleh dosen pengampuh belum berjalan dengan baik. Oleh sebab itu, diperlukan metode yang lebih efektif dan tepat sasaran dalam meningkatkan kualitas pembelajaran. Kesenjangan antara mata kuliah dasar geologi dengan mata kuliah geologi lanjutan yang terjadi pada mahasiswa juga menjadi indikator adanya metode pembelajaran yang kurang tepat (Pramumijoyo et al., 2014). Hal ini mengindikasikan bahwa diperlukan metode pembelajaran yang variatif dan inonatif demi maksimalnya proses pembelajaran pada mata kuliah geologi untuk meningkatkan kualitas pendidikan. Peningkatan kualitas pendidikan dapat dilihat dari keberhasilan proses pembelajaran (Otoluwa et al., 2019)

Kuliah lapangan merupakan metode pembelajaran yang memungkinkan mahasiswa dapat beinteraksi secara langsung dengan objek yang dipelajari. Pembelajaran di lapangan mampu meningkatkan minat belajar mahasiswa geografi (Arinta et al., 2016). Minat belajar akan mempengaruhi kegiatan-kegiatan pembelajaran selanjutnya. Kuliah lapangan geologi yang selama ini dilaksanakan pada program studi pendidikan geografi FKIP Undana berjalan kurang efektif. Ada beberapa kendala yang dihadapi mahasiswa diantaranya: 1) kurang maksimalnya tahap persiapan kegiatan yang berkaitan dengan administrasi dan koordinasi dengan pihak terkait; 2) minimnya literasi mahasiswa mengenai topik kajian; 3) masalah penyiapan instrumen kegiatan; 4) keterampilan pengumpulan data lapangan; dan 5) penyusunan laporan kegiatan.

Lesson study merupakan upaya pengkajian pembelajaran dalam rangka meningkatkan profesional pendidik (Rahayu et al., 2012). (Sukirman, 2011) menjelaskan bahwa lesson study merupakan salah-satu model pembinaan profesi pendidik berkelanjutan dengan prinsip kolegalitas. Lesson study dilakasanakan dengan serangkaian tahapan. (Lewis, 2002), menyatakan bahwa tahapan lesson study yaitu membentuk kelompok, memfokuskan lesson study, merencanakan pembelajaran, mendiskusikan pembelajaran yang telah dilakukan, melakukan refleksi, dan merencanakan tahap-tahap selanjutnya. (Sugiharyanto, 2007) dalam hasil penelitiannya menyatakan bahwa topografi yang kasar cocok untuk pembelajaran lapangan geografi fisik. Atas dasar pertimbangan tersebut sehingga peneliti menentukan lokasi penelitian di dua lokasi dengan topografi kasar yaitu pada bagian tengah Pulau Flores (Kabupaten Ende) dan wilayah bagian utara Kabupaten Kupang. Dengan pelaksanaan lesson study diharapkan kualitas pembelajaran lapangan geologi dapat ditingkatkan dan kelemahan-kelemahan pembelajaran yang dilakukan dapat diperbaiki pada tahap selanjutnya. Berdasarkan latar belakang di atas peneliti ingin memfokuskan penelitian pada peningkatan kualitas pembelajaran lapangan geologi pada mahasiswa geografi FKIP Undana melalui lesson study.

\section{Metode}

\subsection{Jenis peneitian, teknik pengumpulan data, dan analisis data}

Jenis Penelitian ini adalah deskriptif survey. Populasi penelitian adalah mahasiswa yang memprogram mata kuliah Praktek Kerja Lapangan Geografi khusus kelompok dengan topik geologi. Instrumen Pengumpulan data berupa lembar observasi pembelajaran dan lembar refleksi sesuai tujuan penelitian. Data yang terkumpul akan dianalisis dengan menggunakan statistik deskriptif. Dosen model dipilih satu orang dengan dibantu tiga orang observer dan satu dosen penilai..

\subsection{Lokasi Penelitian}

Lokasi kuliah lapangan dilaksanakan di dua tempat dengan karakteristik topografi kasar. Lokasi pertama pada gambar 1 Peta lokasi kuliah lapangan di Kabupaten Ende, di Danau Kelimutu Kabupaten Ende dan lokasi kedua pada gambar 2. Peta lokasi kuliah lapangan di Kabupaten Kupang di Gunung Fatuleu Kabupaten Kupang. 


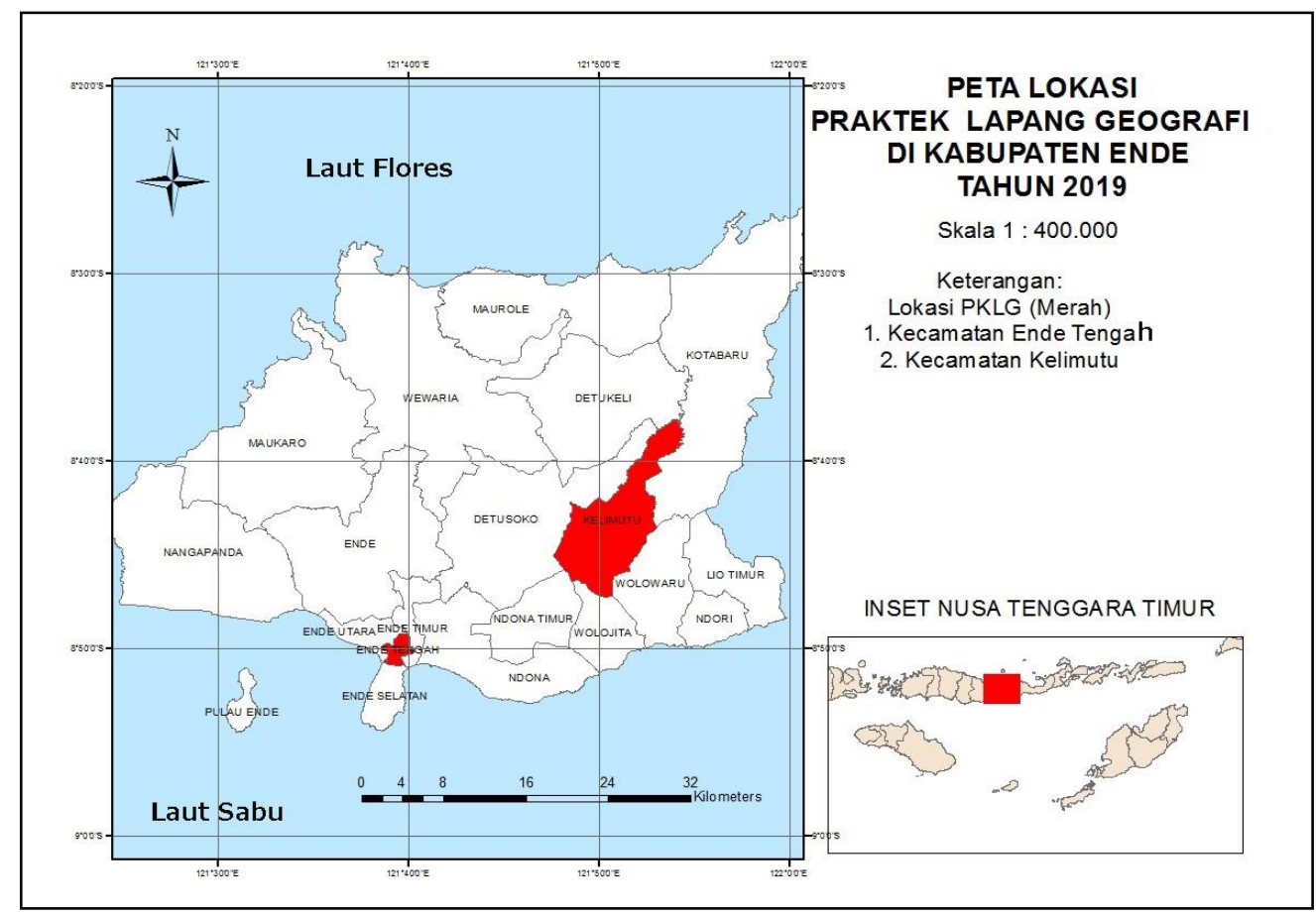

Gambar 1. Peta lokasi kuliah lapangan di Kabupaten Ende

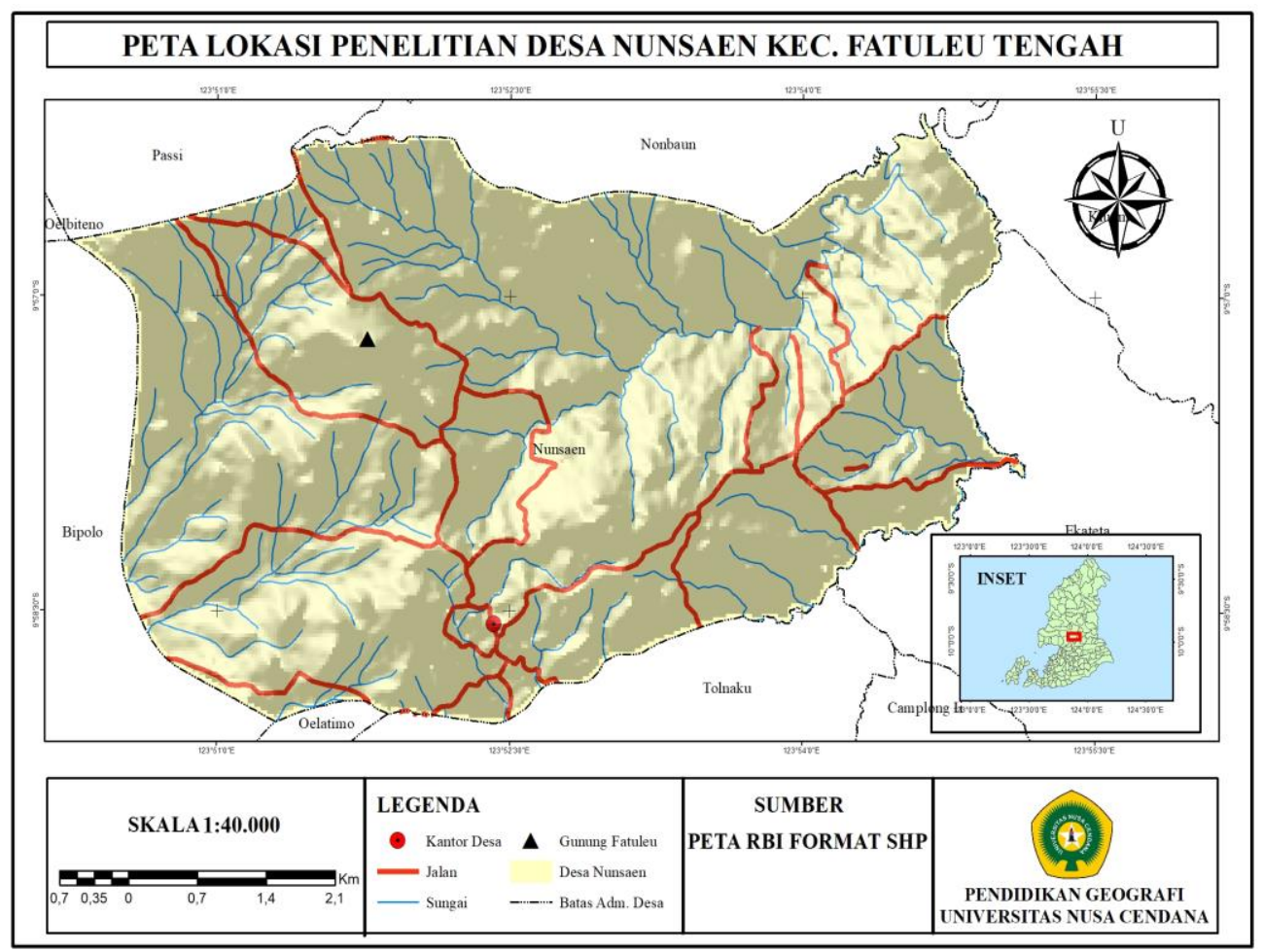

Gambar 2. Peta lokasi kuliah lapangan di Kabupaten Kupang 


\section{Hasil dan Pembahasan}

Alur kegiatan pembelajaran lapangan untuk topik geologi adalah: 1) Kegiatan pra-lapangan. Pada kegiatan ini dosen model melakukan pembimbingan teknis persiapan kegiatan lapangan terkait persuratan (administrasi), penyiapan instrumen, jadwal, dan survey tempat pelaksanaan kegiatan kepada mahasiswa, sementara observer dan dosen penilai mengamati jalannya pembimbingan; 2) Kegiatan lapangan. Pada kegiatan ini dosen model memberikan pembekalan terakhir di lapangan dalam bentuk briefing sebelum menuju titik pengamatan. Breafing membantu dosen untuk mengidentifikasi kebutuhan dan persiapan pembelajaran agar berjalan dengan baik. Setelah itu mahasiswa dipersilahkan melakukan pengamatan dan pengumpulan data yang didampingi oleh dosen model. Setelah selesai mahasiswa diminta oleh dosen model untuk merapikan catatan lapangan dalam bentuk laporan sementara untuk didiskusikan kembali di posko penginapan. Dosen penilai dan observer memantau jalannya kegiatan; 3) Kegiatan pelaporan. Pada kegiatan ini dosen model dan mahasiswa melakukan pertemuan untuk membahas format laporan akhir. Dosen penilai dan observer memantau jalannya kegiatan. Analisis pembelajaran lapangan geologi dilakukan pada dua lokasi dengan hasil sebagai berikut:

\subsection{Analisis pembelajaran lapangan geologi di lokasi 1}

Kegiatan kuliah lapangan geologi pada lokasi pertama dilaksanakan di Danau Kelimutu Kabupaten Ende dari tanggal 18 sampai 21 oktober 2019. Pembimbingan teknis sudah dimulai tiga minggu sebelum jadwal pemberangkatan. Kondisi perjalanan laut menuju Kabupaten Ende memerlukan waktu lebih dari 12 jam sehingga kegiatan lapangan baru dapat dilaksanakan pada tanggal 20 Oktober 2019. Berikut adalah tim dosen dan kelompok mahasiswa yang mengkaji topik geologi:

Tabel 1. Dosen Model, dosen penilai, observer, dan praktikan kuliah Lapangan Geologi di Lokasi 1

\begin{tabular}{|c|c|c|c|c|}
\hline No. & Nama & Jabatan & & Peran \\
\hline 1. & Arfita Rahmawati, S.Pd. M.Pd. & $\begin{array}{ll}\text { Dosen } & \text { Pengampu } \\
\text { Kuliah } & \end{array}$ & Mata & Dosen Model \\
\hline 2. & $\begin{array}{l}\text { Muhammad Husain Hasan, } \\
\text { S.Pd. M.Pd. }\end{array}$ & $\begin{array}{l}\text { Dosen Pengampu } \\
\text { Kuliah }\end{array}$ & Mata & Dosen Penilai \\
\hline 3. & $\begin{array}{l}\text { Bella Theo T. Pamungkas, S.Pd. } \\
\text { M.Pd. }\end{array}$ & Dosen Program Studi & & Observer \\
\hline 4. & Sunimbar, S.Pd. M.Pd. & $\begin{array}{l}\text { Dosen Pengampu } \\
\text { Kuliah }\end{array}$ & Mata & Observer \\
\hline 5. & Samuel Uki & Mahasiswa & & Observer \\
\hline 6. & Ferawati Nenotek & Mahasiswa & & Praktikan Geologi \\
\hline 7. & Isabella Sintia Fontes & Mahasiswa & & Praktikan Geologi \\
\hline 8. & Benedikta Monika M. Maing & Mahasiswa & & Praktikan Geologi \\
\hline 9. & Susasna Imelda Parung & Mahasiswa & & Praktikan Geologi \\
\hline 10. & Yelti Kikhau & Mahasiswa & & Praktikan Geologi \\
\hline 11. & Klaudius Jehamut & Mahasiswa & & Praktikan Geologi \\
\hline 12. & Ledi C. Liu & Mahasiswa & & Praktikan Geologi \\
\hline 13. & Noviana Antonia Giri & Mahasiswa & & Praktikan Geologi \\
\hline
\end{tabular}

Sumber: Laporan PKLG 2019 
Analisis kegiatan pembelajaran lapangan dimulai dari pra-lapangan, selama pengamatan/pengumpulan data lapangan, dan penyusunan laporan akhir. Kinerja setiap tahapan pembelajaran lapangan geologi disajikan pada tebel berikut:

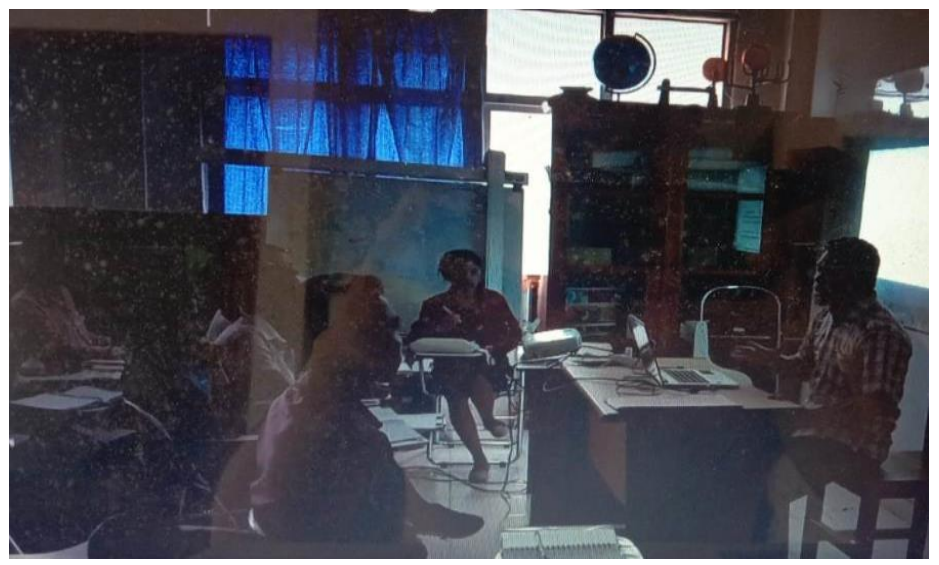

Gambar 3. Kegiatan pembekalan teknis kuliah lapangan Sumber: Foto kegiatan prodi, 2019
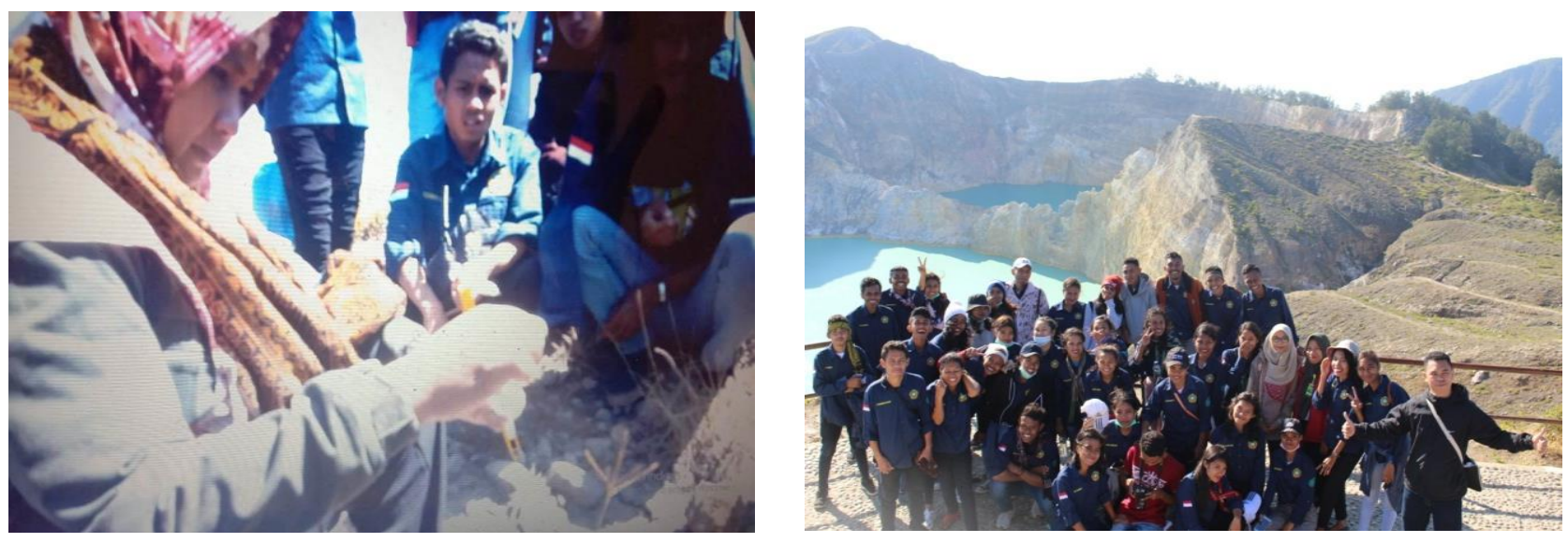

Gambar 4. Kegiatan selama di lapangan

Sumber: Data lapangan, 2019

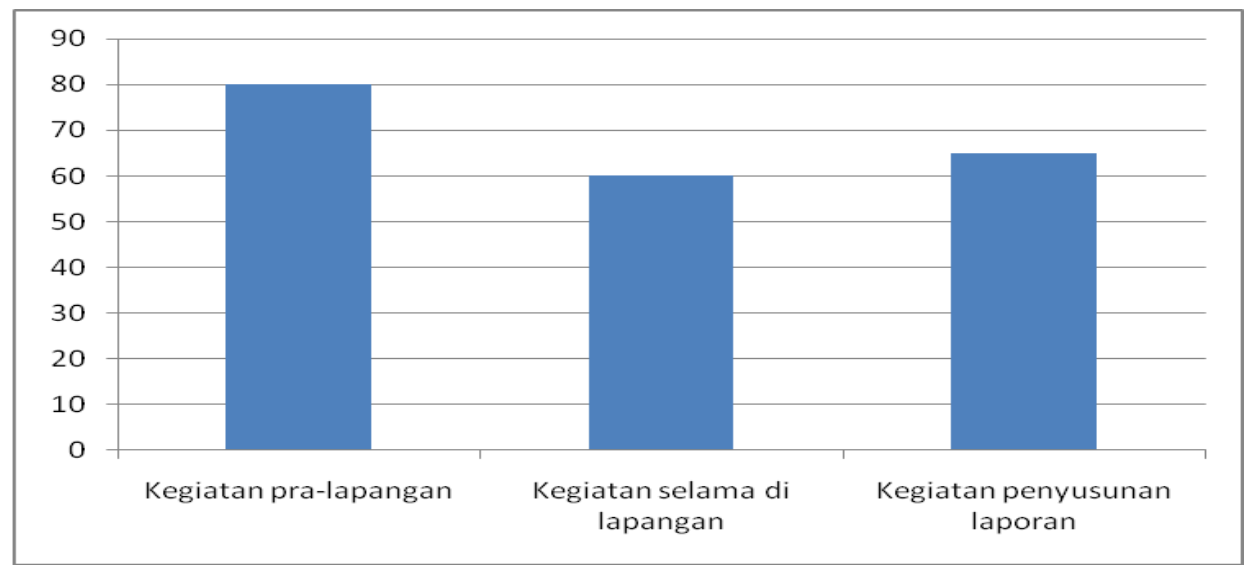

Gambar 5. Capaian rerata skor hasil observasi di lokasi 1

Sumber: Pengolahan data penelitian, 2019

Dari data di atas terlihat bahwa kinerja dosen model pada semua tahap pembelajaran belum tuntas. Pada kegiatan pra-lapangan mendapatkan rerata skor observasi 80 dimana dosen model telah mampu memberikan 
pembekalan yang cukup kepada mahasiswa seperti menyediakan panduan praktikum lapangan geologi yang di dalamnya dijelaskan tentang variabel-variabel atau aspek-aspek geologi yang diteliti, penentuan instrumen, langkah kerja, dan penyusunan laporan. Untuk kegiatan di lapangan mendapatkan skor yang masih rendah yaitu 60. Ada beberapa kekurangan diantaranya instrumen lapangan yang tidak lengkap sehingga dosen model tidak bisa maksimal dalam mendampingi pengumpulan data. Untuk kegiatan penyusunan laporan juga mendapatkan skor yang belum maksimal yaitu 65 dikarenakan data lapangan tidak lengkap. Untuk mendapatkan gambaran lebih lanjut, dilakukan analisis data refleksi pembelajaran lapangan geologi dengan teknik the way conference (Nofrion, 2009) sebagai berikut:

Tabel 2. Refleksi pembelajaran lapangan geologi lokasi 1

\begin{tabular}{|c|c|c|c|c|}
\hline No. & Observer & Kelebihan & Kelemahan & Solusi \\
\hline 1. & BTTP & $\begin{array}{l}\text { Administrasi kegiatan dan } \\
\text { pembekalan mahasiswa } \\
\text { berjalan dengan baik. }\end{array}$ & $\begin{array}{lr}\text { Koordinasi } & \text { dan } \\
\text { penekanan } & \text { ke } \\
\text { mahasiswa } & \text { untuk } \\
\text { penyiapan } & \text { instrumen } \\
\text { lapangan. } & \end{array}$ & $\begin{array}{l}\text { Perlu lebih tegas } \\
\text { kepada } \\
\text { mahasiswa agar } \\
\text { dapat melengkapi } \\
\text { instrumen } \\
\text { lapangan } \\
\text { sebelum } \\
\text { keberangkatan ke } \\
\text { lokasi. }\end{array}$ \\
\hline 2. & $S$ & $\begin{array}{l}\text { Adanya modul praktikum } \\
\text { sebagai pedoman bagi } \\
\text { mahasiswa. }\end{array}$ & $\begin{array}{l}\text { Laporan akhir kurang } \\
\text { sistematis. }\end{array}$ & $\begin{array}{l}\text { Perlu } \\
\text { pendampingan } \\
\text { berupa asistensi } \\
\text { dan konsultasi } \\
\text { draft laporan } \\
\text { akhir sebelum } \\
\text { dikumpulkan. }\end{array}$ \\
\hline 3. & SU & $\begin{array}{l}\text { Gaya presentasi yang baik } \\
\text { pada saat kegiatan } \\
\text { pembekalan. }\end{array}$ & $\begin{array}{lr}\text { Mahasiswa } & \text { kurang } \\
\text { disiplin } & \text { selama } \\
\text { kegiatan pembekalan } \\
\text { dan selama di } \\
\text { lapangan. }\end{array}$ & $\begin{array}{lr}\text { Perlu } & \text { adanya } \\
\text { tindakan } & \text { tegas } \\
\text { kepada } & \\
\text { mahasiswa } & \text { yang } \\
\text { tidak } & \text { disiplin } \\
\text { antara } & \text { lain } \\
\text { dengan } & \text { memberi } \\
\text { punishment. }\end{array}$ \\
\hline
\end{tabular}

Sumber: Pengolahan data lapangan, 2019

Hasil observasi pada lembar refleksi pembelajaran ini dijadikan dasar untuk kegiatan refleksi yang dilaksanakan setelah selesainya kegiatan pembelajaran lapangan. Kegiatan refleksi pertama menjadi dasar untuk melaksanakan kegiatan plan 2 yaitu kegiatan kuliah lapangan topik geologi pada kegiatan berikutnya. Aspek yang perlu diperhatikan adalah kelengkapan instrumen, pengawasan dan pendampingan mahasiswa secara lebih intensif selama di lapangan dan selama penyusunan laporan kegiatan.

\subsection{Analisis pembelajaran lapangan geologi di lokasi 2}

Kegiatan kuliah lapangan geologi pada lokasi kedua dilaksanakan di Gunung Fatuleu Kabupaten Kupang dari tanggal 20 sampai 21 November 2020. Tabel 3. Dosen Model, dosen penilai, observer, dan praktikan kuliah Lapangan Geologi di Lokasi 2 adalah tim dosen dan kelompok mahasiswa yang mengkaji topik geologi

Tabel 3. Dosen Model, dosen penilai, observer, dan praktikan kuliah Lapangan Geologi di Lokasi 2

\begin{tabular}{lllll}
\hline No. & Nama & Jabatan & Peran \\
\hline 1. & Arfita Rahmawati, S.Pd. M.Pd. & Dosen & Pengampu & Mata \\
& & Kuliah & & \\
\hline
\end{tabular}




\begin{tabular}{lllll}
\hline 2. & $\begin{array}{l}\text { Muhammad Husain Hasan, } \\
\text { S.Pd. M.Pd. }\end{array}$ & $\begin{array}{l}\text { Dosen Pengampu } \\
\text { Kuliah }\end{array}$ & Mata & Dosen Penilai \\
\hline 3. & $\begin{array}{l}\text { Bella Theo T. Pamungkas, S.Pd. } \\
\text { M.Pd. }\end{array}$ & $\begin{array}{l}\text { Dosen Pengampu } \\
\text { Kuliah }\end{array}$ & Mata & Observer \\
\hline 4. & Tobias Ola Sabon & Mahasiswa & Observer \\
\hline 5. & Yohanes M. Tolok & Mahasiswa & Observer \\
\hline 6. & Exel Imanuel Mangngi & Mahasiswa & Praktikan Geologi \\
\hline 7. & Meldy Boru & Mahasiswa & Praktikan Geologi \\
\hline 8. & Selfi Lanu & Mahasiswa & Praktikan Geologi \\
\hline 9. & Diana Mbau & Mahasiswa & Praktikan Geologi \\
\hline
\end{tabular}

Sumber: Laporan PKLG 2020
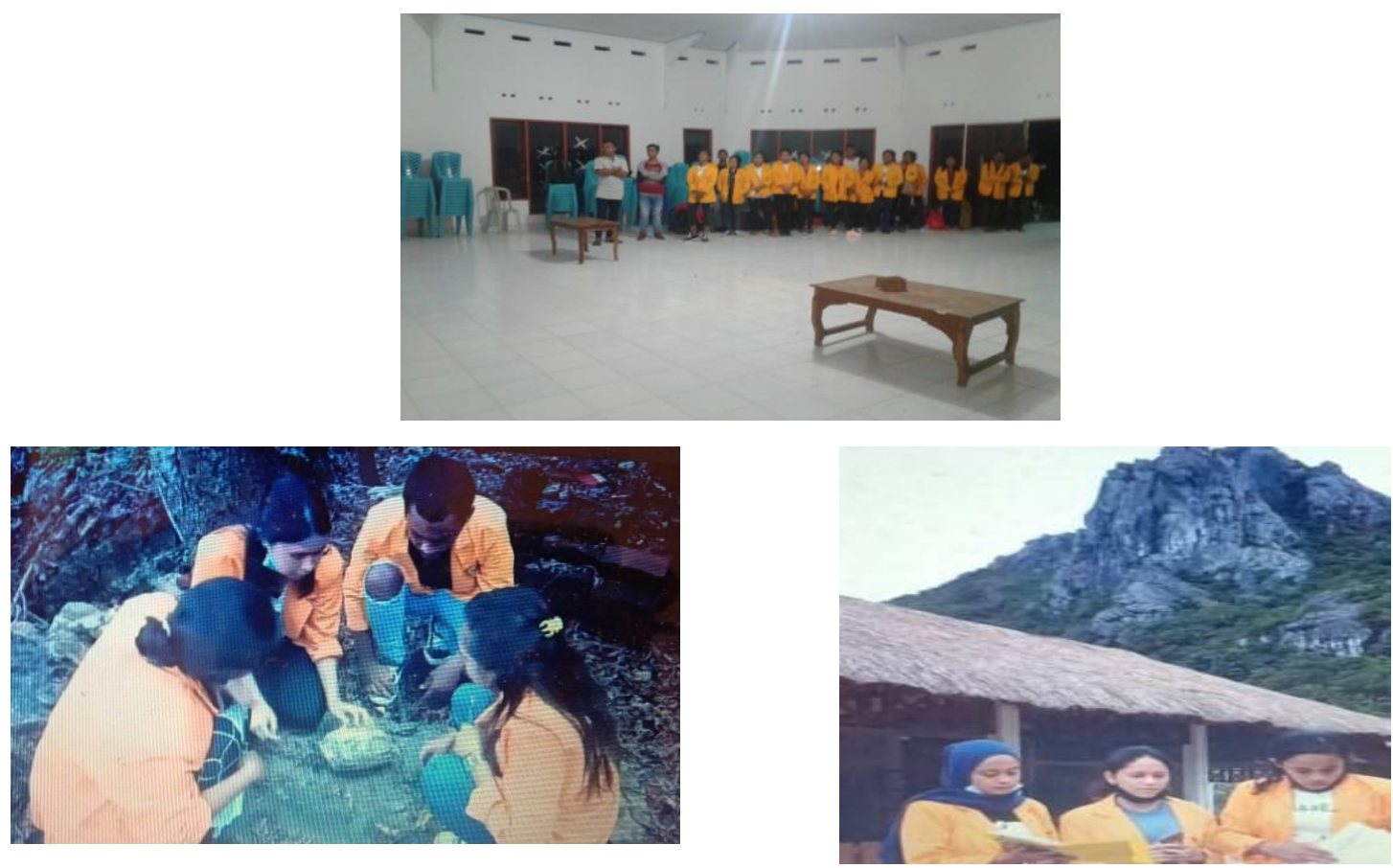

Gambar 6. Kegiatan pembimbingan dan selama di lapangan

Sumber: Foto kegiatan kuliah lapangan, 2020

Analisis kegiatan pembelajaran lapangan dimulai dari pra-lapangan, selama pengamatan/pengumpulan data lapangan, dan penyusunan laporan akhir. Kinerja setiap tahapan pembelajaran lapangan geologi disajikan pada tebel 4 capaian rerata skor hasil observasi di lokasi 2 berikut: 
Tabel 4. Capaian rerata skor hasil observasi di lokasi 2

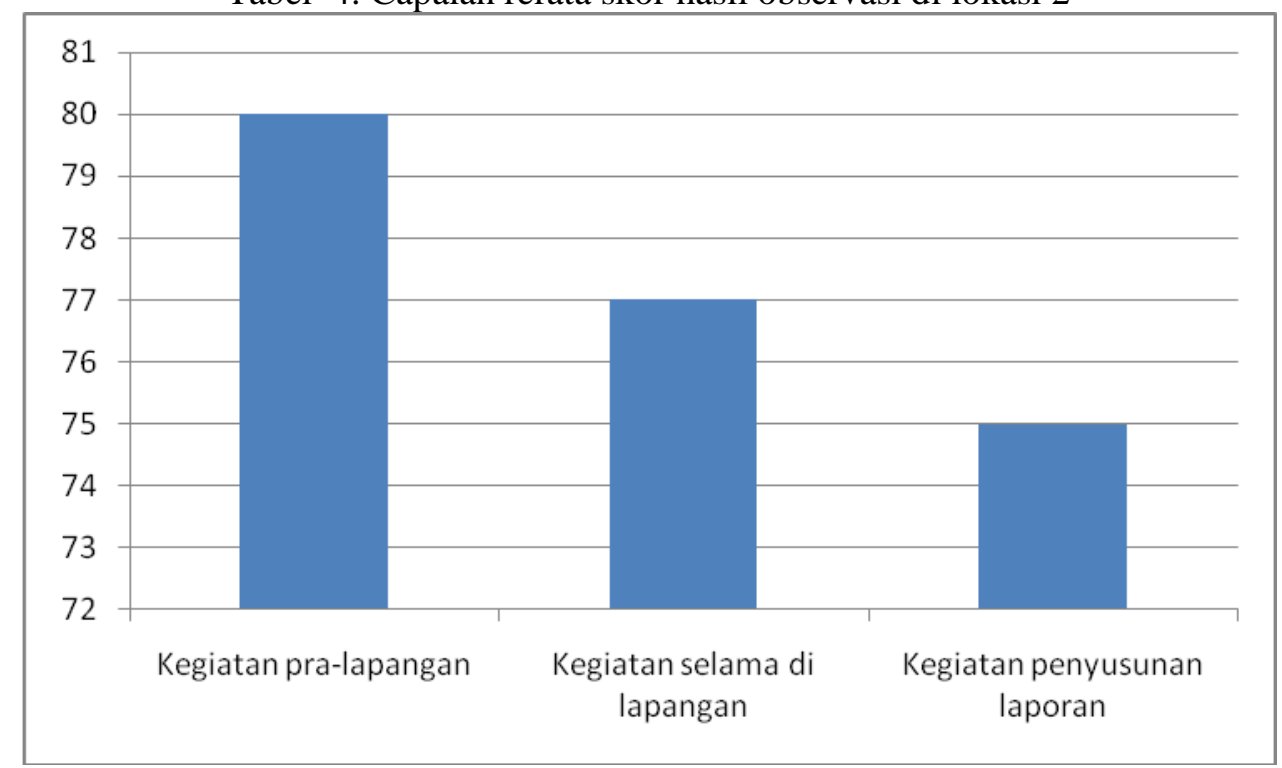

Sumber: Pengolahan data penelitian 2020

Dari tabel Capaian rerata skor hasil observasi di lokasi 2 terlihat bahwa kinerja dosen model pada semua telah mengalami peningkatan. Pada kegiatan pra-lapangan mendapatkan skor 80 dimana dosen model telah mampu memberikan pembekalan yang cukup kepada mahasiswa. Untuk kegiatan di lapangan mendapatkan skor 77. Kegiatan lapangan berlangsung secara sistematis bahkan telah dibuat video dokumenter selama pengumpulan data. Tahapan kegiatan lapangan pada kegiatan lesson study, selain diperoleh saran, masukan juga ditemukan kelemahan dan kelebihan yang terjadi dalam proses pembelajaran, (Alimah \& Susilo, 2013) Untuk kegiatan penyusunan laporan mendapatkan skor 75 dikarenakan data lapangan sudah memenuhi kriteria lengkap meskipun pada bagian kajian pustaka masih perlu diperkaya. Untuk mendapatkan gambaran lebih lanjut, dilakukan analisis data refleksi pembelajaran lapangan geologi dengan teknik wawancara kepada dosen dan mahasiswa yang bertindak sebagai observer/penilai sebagai berikut:1) . Muhammad Husain Hasan (dosen pengasuh mata kuliah) mengungkapkan "Kegiatan kuliah lapangan geologi sudah berjalan dengan baik dan sistematis dari tahap pra-lapangan, selama di lapangan, dan pelaporan kegiatan. Kegiatan selama di lapangan juga dilengkapi dengan video dokumenter sebagai kelengkapan laporan." 2). Tobias Ola Sabon (mahasiswa observer) "Kegiatan kuliah lapangan berlangsung dengan baik dimana dosen pembimbing memberi arahan selama pengamatan dan pengumpulan data." 3). Yohanes Megu Tolok (mahasiswa observer) "Dalam pembelajaran di lapangan, kita tidak sekedar mengamati topik kajian tetapi mengajarkan kita banyak hal seperti kemampuan beradaptasi dalam organisasi kelompok dan masyarakat di lokasi."

Hasil observasi dan refleksi pembelajaran pada kegiatan kuliah lapangan di lokasi 2 menunjukkan peningkatan atau progress yang lebih baik dibandingkan pada lokasi pertama dimana mahasiswa lebih dapat diarahkan dengan baik. Rangkaian kegiatan dosen model dari tahap pra lapangan, kegiatan selama di lapangan, dan kegiatan pelporan menunjukkan peningkatan.

\section{Kesimpulan}

Kegiatan kuliah lapangan topik geologi mengalami peningkatan, proses pembelajaran yang telah didesain oleh dosen pengampuh matakuliah memperlihatkan nilai yang diperoleh mahasiswa hanya 60 pada pelaksaan kuliah lapangan pertama, setelah dilakukan refleksi dan perbaikan pada lokasi dua naik hingga 80. Hal ini 
terjadi karena pada Tahapan kegiatan, instrumen pengumpulan data, keefektivan dosen dalam pembimbingan dan pengawasan mahasiswa menjadi poin-poin penting telah ditingkatkan.

\section{Referensi}

Alimah, S., \& Susilo, H. (2013). Desain Pembelajaran Biologi dengan Model Experiential Jelajah Alam Sekitar melalui Lesson Study. Proceeding Biology Education Conference .... https://jurnal.uns.ac.id/prosbi/article/viewFile/6312/5696

Arinta, D., Utaya, S., \& Astina, I. (2016). Implementasi Pembelajaran Kuliah Kerja Lapangan Dalam Meningkatkan Minat Belajar Mahasiswa Program Studi Pendidikan Geografi Universitas Negeri Malang. Jurnal Pendidikan: Teori, Penelitian, Dan Pengembangan, 1(8), 1665-1670-1670. https://doi.org/10.17977/jp.v1i8.6705

Lewis, C. C. (2002). Lesson Study: A Handbook of Teacher-Led Instructionl Change. Research for Better Schools, Inc.

Nofrion. (2009). Narasumber Nasional Program Sekolah BERMUTU Berbasis Zonasi melalui LSLC Kementerian Pendidikan dan Kebudayaan RI dan Tim Pengembang LSLC Universitas Negeri Padang.

Otoluwa, Y., Eraku, S., \& Yusuf, D. (2019). PENGEMBANGAN MEDIA PEMBELAJARAN BERBASIS LECTORA INSPIRE YANG DIINTEGRASIKAN DENGAN CAMTASIA STUDIO PADA MATA PELAJARAN GEOGRAFI MATERI SISTEM INFORMASI GEOGRAFI. JAMBURA GEO EDUCATION JOURNAL, 1(1), 01-08. https://doi.org/10.34312/jgej.v1i1.4041

Pramumijoyo, Wijono, \& Hariadi. (2014). Evaluasi Pembelajaran Geologi Ditinjau Dari Keberhasilan Pembelajaran Mata Kuliah Metode Geologi Lapangan Di Jurusan Teknik Geologi FT UGM. 897-902.

Prasad, A. H. H. (2013). Mengamati Fenomena Geografi. Digna Pustaka.

Rahayu, P., Mulyani, S., \& Miswadi, S. S. (2012). Pengembangan pembelajaran IPA terpadu dengan menggunakan model pembelajaran problem base melalui lesson study. Jurnal Pendidikan IPA Indonesia, 1(1), 63-70. https://doi.org/10.15294/jpii.v1i1.2015

Sugiharyanto, S. (2007). Kelayakan Wilayah Perbukitan Jiwo Sebagai Laboratorium Alam Untuk Praktik Kerja Lapangan Geografi Fisik Mahasiswa Jurusan Pendidikan Geografi. Jurnal Geomedia, 5(1), 1-12.

Sukirman. (2011). Implementasi Pendidikan Karakter Dalam Perkuliahan Melalui Lesson Study (Suatu Alternatif).

Yunus, H. S. (2010). Metodologi Penelitian Wilayah Kontemporer. Pustaka Pelajar.

Zuhdi, M. (2019). Buku Ajar Pengantar Geologi. Duta Pustaka Ilmu. 